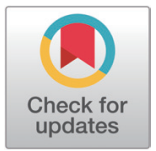

Received: Jan 17, 2021

Revised: Jan 26, 2021

Accepted: Feb 1, 2021

${ }^{*}$ Corresponding author Devon L Ragen

Department of Animal and Range Sciences, Montana State University, Bozeman, MT 59717, USA

Tel: +1-406-994-7749

E-mail: Devon.ragen@montana.edu

Copyright $(\subset) 2021$ Korean Society of Animal Sciences and Technology. This is an Open Access article distributed under the terms of the Creative Commons Attribution Non-Commercial License (http:// creativecommons.org/licenses/by$\mathrm{nc} / 4.0 /$ ) which permits unrestricted non-commercial use, distribution, and reproduction in any medium, provided the original work is properly cited.

ORCID

Devon L Ragen

https://orcid.org/0000-0002-0140-1581 Jane A Boles

https://orcid.org/0000-0001-8381-3434

Competing interests

No potential conflict of interest relevant to this article was reported.

Funding sources

We would like to thank WSARE for the funding of this project: "Integrating Livestock into Cropping Systems and the Impacts on Soil Health" SW17-080.

\section{Evaluating the effects of finishing diet and feeding location on sheep performance, carcass characteristics, and internal parasites}

\author{
Devon L Ragen ${ }^{1 *}$, Molly R Butler ${ }^{1}$, Jane A Boles ${ }^{1}$, William A Layton ${ }^{2}$, \\ Thomas M Craig ${ }^{3}$ and Patrick G Hatfield ${ }^{1}$ \\ ${ }^{1}$ Department of Animal and Range Sciences, Montana State University, Bozeman, MT 59717, USA \\ ${ }^{2}$ Montana Department of Livestock, Bozeman, MT 59718, USA \\ ${ }^{3}$ Department of Veterinary Pathobiology, Texas A\&M University, College Station, TX 77843, USA
}

\section{Abstract}

A 3 yr experiment was conducted to evaluate the influence of diet and feeding location on animal performance, carcass characteristics, whole blood counts, and internal parasite burden of lambs assigned to 1 of 4 treatments: 1) confinement fed $71 \%$ alfalfa, $18 \%$ barley pellet, $5 \%$ molasses, $0.013 \%$ Bovatec, $6.1 \%$ vitamin/mineral package diet (CALF), 2) confinement fed $60 \%$ barley, $26 \%$ alfalfa pellet, $4 \%$ molasses, $2.5 \%$ soybean-hi pro, $0.016 \%$ Bovatec, $7.4 \%$ vitamin/mineral package diet (CBAR), 3) field fed $71 \%$ alfalfa, $18 \%$ barley pellet, $5 \%$ molasses, $0.013 \%$ Bovatec, $6.1 \%$ vitamin/mineral package diet (FALF), and 4 ) field fed $60 \%$ barley, $26 \%$ alfalfa pellet, $4 \%$ molasses, $2.5 \%$ soybean-hi pro, $0.016 \%$ Bovatec, $7.4 \%$ vitamin/mineral package diet (FBAR). A year $\times$ location interaction was detected for ending body weight (BW), average daily gain (ADG), and dry matter intake (DMI); therefore results are presented by year. In all years, cost of gain and DMI were greater for CALF and FALF than for CBAR and FBAR feed treatments $(p \leq 0.03)$. In yr 2 and 3 field treatments had greater ending BW and $A D G$ than confinement treatments. For all years, diet did not affect ending BW or ADG. In yr 1 dressing percent and rib eye area were greater for field finished lambs than confinement finished $(p \leq 0.02)$ and Warner-Bratzler shear force was greater for CALF and FALF $(p=0.03)$. In yr 2 lambs in FALF and FBAR treatments had greater leg scores and conformation than CALF and CBAR $(p=0.09)$. In yr 1, FALF had a greater small intestine total worm count than all other treatments. In yr 1, ending Trichostrongyle type egg counts were greater for FALF ( $p=$ 0.05). In yr 2, ending Nematodirus spp. egg counts were greater for FALF and lowest for CBAR $(p<0.01)$. Abomasum Teladorsagia circumcinta worm burden was greater in CALF than all other treatments $(p=0.07)$ in yr 2 . While field finishing lambs with a grain- or forage-based diet we conclude that it is possible to produce a quality lamb product without adverse effects to animal performance, carcass quality or increasing parasite burdens.

Keywords: Carcass, Confinement, Field, Finishing, Parasites, Sheep 
Acknowledgements

The authors would like to acknowledge

Ryan Knuth for his assistance with the SAS

software. We also appreciate the help of

Chad Page, Olivia Fernandez, and Miriah

Butler for field work.

Availability of data and material Upon reasonable request, the datasets of this study can be available from the corresponding author.

\section{Authors' contributions}

Conceptualization: Boles JA, Hatfield PG.

Data curation: Ragen DL, Butler MR.

Formal analysis: Ragen DL, Butler MR.

Methodology: Ragen DL, Butler MR.

Investigation: Ragen DL, Butler MR.

Writing - original draft: Ragen DL, Butler MR.

Writing - review \& editing: Ragen DL, Boles

JA, Layton WA, Craig TM, Hatfield PG.

Ethics approval and consent to participate All animal procedures were approved by the Montana State University Agricultural Animal Care and Use Committee (Protocol \#2013AA07 approved October 29, 2013).

\section{INTRODUCTION}

Integrated crop and livestock systems as an alternative to confinement feedlot operations have gained popularity in recent years. The excretion and concentration of manure at concentrated animal feeding operations has resulted in environmental concerns associated with nuisance issues (odors, disease vectors), water quality, and air quality [1]. Conversely, the application of manure to soil provides potential benefits including improving the fertility, structure, water holding capacity of soil, increasing soil organic matter and reducing the amount of synthetic fertilizer needed for crop production [2-4]. Incorporating livestock into cropping systems may offer alternative uses of crops and provide new grazing opportunities for livestock producers [5]. It also offers an alternative to traditional stubble management, and enables improved pest management [6-8]. In Montana, sheep producers commonly manage their flock on rangeland or pasture during the grazing months of spring and summer and feed harvested forages during the fall and winter. Lambs raised for meat production are typically finished in a confinement feedlot operation [9].

Internal parasitism of grazing livestock is a significant world-wide disease problem [10,11]. Gastrointestinal parasites (GIP) in the abomasum and small intestine cause extensive protein loss in the digestive tracts of sheep [12] and failure to control GIP results in poor animal growth rates and thrift, and can result in animal mortality [13]. Previous research has reported that gastrointestinal nematode eggs per gram (EPG) were lowest in lambs fed in confinement, moderate in semiconfinement, and highest in grazing lambs [14]. Research by Ebrahim [15] revealed that blood samples taken from sheep infested with GIP had a significant decrease in hemoglobin, packed cell volume and red blood cell count values, while white blood cell count was significantly increased, compared to blood samples from a group of sheep that were parasite-free.

Previous research has only focused on grazed or harvested forage as the diet for finishing livestock and there is an increasing demand for non-confinement, forage-fed animals which are stimulating market interest in alternative production systems [16,17]. Providing a finishing ration to livestock on cropland is an unconventional way to finish livestock while adding manure to the soil. The objectives of this $3 \mathrm{yr}$ study were to compare the effects of finishing diet and location on the performance, carcass characteristics, whole blood counts, and parasite loads of weaned, crossbred lambs.

\section{MATERIALS AND METHODS}

\section{Ethics statement}

All animal procedures were approved by the Montana State University Agricultural Animal Care and Use Committee (Protocol \#2013-AA07 approved October 29, 2013).

\section{Sampling}

Ninety crossbred lambs (ewes and wethers; Blackface $\times$ Western whiteface; 6-mo-old; body weight $[\mathrm{BW}]=35.6 \pm 5.7 \mathrm{~kg}$ ) and 18 Targhee lambs (ewes; 6-mo-old; BW = $35.8 \pm 5.2 \mathrm{~kg}$ ) were used in yr 1 (September 25 to November 25) of the study. Targhee ewe lambs were used because of an insufficient number of crossbred lambs in yr 1. The Targhee ewes were evenly distributed through all treatments. One hundred and eight crossbred lambs (ewes and wethers; Blackface $\times$ Western whiteface; 5-mo-old; BW = 31.8 $\pm 4.7 \mathrm{~kg}$ ) were used in yr 2 (September 3 to November 3 ) of the study. One hundred and eight crossbred lambs (ewes and wethers; Blackface $\times$ Western whiteface; 5 -mo-old; BW $=36.8 \pm 5.7 \mathrm{~kg}$ ) were used in yr 3 (September 1 to November 5) of the study. For yr 1, yr 2 and yr 3, lambs were transported to the Fort Ellis Research Facility $\left(45^{\circ} 40^{\prime} \mathrm{N}, 111^{\circ} 2\right.$ 'W, 
altitude 1,468 m) in Bozeman, Montana, USA on September 19th, September 1st, and August 30th, respectively. Mean monthly air temperature at the site ranges from $-5.6^{\circ} \mathrm{C}$ in January to $19^{\circ} \mathrm{C}$ in July and the total annual precipitation (113-yr average) is $465 \mathrm{~mm}$. On d 0 all lambs were placed in a dry lot pen and held off of feed and water overnight. On $\mathrm{d} 1$ lambs were weighed, and paintbranded for identification purposes. Lambs were then stratified by BW and sex and allocated to treatments. In all years, the four treatments consisted of: 1 ) confinement fed $71 \%$ alfalfa, $18 \%$ barley pellet diet (CALF), 2) confinement fed 60\% barley, 26\% alfalfa pellet diet (CBAR), 3) field fed 71\% alfalfa, 18\% barley pellet diet (FALF), and 4) field fed 60\% barley, $26 \%$ alfalfa pellet diet (FBAR) (Table 1).

For all three years of the study, pen was the experimental unit with nine lambs per pen in confinement (4 pens total). Field was the experimental unit with six fields per treatment (12 fields total), with six lambs per field. Harvest occurred at the end of the $60 \mathrm{~d}$ finishing period for $\mathrm{yr} 1$ and yr 2; carcass data was not collected in yr 3 as lambs were not harvested the third year of the study.

All lambs on CBAR and FBAR treatment diets had a step-up period of 2 weeks, during which a combination of the barley and alfalfa pellets were fed to lambs in 2 to 3 day increments (25-75, 35-65, 45-55, 55-45, 65-35, 75-25, 85-15, and 100-0 percent respectively). Lambs being field finished, both FALF and FBAR, were on organic wheat stubble fields measuring $15.2 \mathrm{~m}$ by $44.2 \mathrm{~m}$ and fed from self-feeders. Self-feeders were moved to a different area of the field at $\sim 30 \mathrm{~d}$ to help distribute manure and urine. The winter wheat stubble fields used for this experiment were part of a common 5-yr crop rotation planted at the site: 1) safflower under-sown to biennial sweet clover, 2) sweet clover cover crop/green manure, 3) winter wheat, 4) lentils, and 5) winter wheat. Further details of the farm management practices used at the research site can be found in [18-21].

Confinement finishing took place in dry lot pens and used a GrowSafe feed intake system (GrowSafe Systems, Airdrie, AB, Canada) to measure intake. GrowSafe is a feed intake acquisition technology using an electronic radio frequency identification (RFID) system that has enabled researchers and producers to monitor individual animal intake and behavior to more precisely evaluate feed efficiency and health status [22]. GrowSafe records feeding behavior traits such as total intake, frequency and duration of feeding, and eating rate for each individual animal through

Table 1. Nutrient concentration of treatment diets, \% DM basis, and cost of treatment diets

\begin{tabular}{|c|c|c|c|c|c|c|}
\hline \multirow{3}{*}{ Item } & \multirow{2}{*}{\multicolumn{2}{|c|}{$\frac{\text { Yr 1 }}{\text { Treatment }^{1)}}$}} & \multirow{2}{*}{\multicolumn{2}{|c|}{$\begin{array}{c}\text { Yr } 2 \\
\text { Treatment }\end{array}$}} & \multirow{2}{*}{\multicolumn{2}{|c|}{$\begin{array}{c}\text { Yr } 3 \\
\text { Treatment }\end{array}$}} \\
\hline & & & & & & \\
\hline & $\mathrm{ALF}^{2)}$ & $\mathrm{BAR}^{3)}$ & ALF & BAR & ALF & BAR \\
\hline $\mathrm{DM}(\%)$ & 89.91 & 90.14 & 90.13 & 89.66 & 89.71 & 89.38 \\
\hline $\mathrm{CP}(\%)$ & 20.6 & 17.5 & 18 & 18 & 21.3 & 16.3 \\
\hline ADF (\%) & 30.6 & 15.6 & 33.3 & 21 & 32.5 & 16.9 \\
\hline NDF (\%) & 43 & 28.7 & 42.4 & 31.9 & 39.8 & 30.4 \\
\hline TDN (\%) & 67.7 & 84.8 & 64.6 & 78.6 & 63.6 & 83.3 \\
\hline NEm (Mcal/lbs) & 0.68 & 0.89 & 0.64 & 0.81 & 0.63 & 0.87 \\
\hline NEg (Mcal//bs) & 0.41 & 0.59 & 0.37 & 0.55 & 0.36 & 0.58 \\
\hline Cost/ton (\$) & 452.00 & 407.20 & 411.60 & 366.40 & 406.40 & 341.60 \\
\hline
\end{tabular}

${ }^{1)}$ Diets were provided for ad libitum intake.

${ }^{2)}$ ALF: pellet containing $71 \%$ alfalfa, $18 \%$ barley, $5 \%$ molasses, $0.013 \%$ Bovatec, and $6.1 \%$ vitamin/mineral package; fed in both confinement and in the field.

${ }^{3}$ BAR: pellet containing $60 \%$ barley, $26 \%$ alfalfa, $4 \%$ molasses, $2.5 \%$ soybean-hi pro, $0.016 \%$ Bovatec, and $7.4 \%$ vitamin/mineral package; fed in both confinement and in the field.

DMI, dry matter; $C P$, crude protein; ADF, acid detergent fiber; NDF, neutral detergent fiber; TDN, total digestible nutrients; $\mathrm{NE}_{\mathrm{m}}$ net energy for maintenance. 
the use of RFID tags that provide a continuous transmission of data to a computer located at the facility. The lambs in each confinement treatment, CALF and CBAR, were housed together in an 11.3 by $7.1 \mathrm{~m}$ pen with one GrowSafe bunk; modifications were made to the beef cattle stanchions through elevated platforms for sheep.

Prior to all weigh days, animals were kept in a separate dry lot pen where feed and water were withheld overnight for approximately $16 \mathrm{~h}$. Each lamb's BW was recorded at start and at the end of the trial. Average daily gain (ADG) was calculated for the entire $\sim 2$ mo trial period for each year. Daily dry matter intake (DMI) was determined between days that BW was recorded for all lambs and the average ratio of gain to feed (G:F) was calculated between weigh days by dividing ADG by average daily DMI. Cost of gain was calculated by multiplying G:F by cost per $\mathrm{kg}$ of feed. Feed cost was determined by the purchase price of the treatment diets which was based on current market value (Table 1). The higher price of feed in yr 1 was due to a persistent drought that increased the demand for hay as well as lingering winter temperatures that wilted spring crops.

\section{Carcass data}

Carcass data was only collected for yr 1 and yr 2. At the end of yr 1 and yr 2, 32 wether lambs (8 from each treatment) were transported to Pioneer Meats in Big Timber, MT where harvest occurred the following day, using standard industry practices for a small packing plant. After harvest, carcasses were hung by the Achilles tendon, a hot carcass weight was recorded, and dressing percentage was measured. Carcasses were chilled for $24 \mathrm{~h}$ at $4^{\circ} \mathrm{C}$ and then transported to the Montana State University Meat Lab for further processing and data collection.

An experienced evaluator obtained individual-level carcass data. These measurements included back fat depth, rib-eye area, leg score, conformation, flank streaking, and quality grade. Additionally, a sample of four rib chops were obtained from the posterior portion of the left longissimus thoracis, vacuum-packaged and frozen at $-20^{\circ} \mathrm{C}$ for later tenderness analysis. Warner-Bratzler shear force (WBSF) was determined on cooked and chilled rib chops. Samples were defrosted for $24 \mathrm{~h}$ at $4^{\circ} \mathrm{C}$, dried, weighed, and broiled in an electric oven until an internal temperature of $35^{\circ} \mathrm{C}$ was reached. Temperature was monitored using a Digi Sense Scanning Thermometer from Cole Palmer (Vernon Hills, IL, USA) fitted with copper constantan needle thermocouples (Omega Engineering) placed in the geometric center of the chop. All chops were turned over when the temperature reached $35^{\circ} \mathrm{C}$ and continued cooking until a final internal temperature of $71 \pm 1^{\circ} \mathrm{C}$ was reached at which point chops were removed from the heat source. Samples were bagged and allowed to chill at $4^{\circ} \mathrm{C}$ for at least $1 \mathrm{~h}$. Samples were then reweighed to determine cook loss, and two circular cores measuring $1.27 \mathrm{~cm}$ in diameter were obtained parallel to the fiber direction using a hand-held coring device (cork borer) with a total of 6 cores collected from 3 chops. Cores were allowed to reach room temperature prior to being sheared perpendicular to the fiber direction using a TMS90 Texture System (Food Technology, Rockville, MD, USA) fitted with a Warner-Bratzler shear attachment (crosshead speed $200 \mathrm{~mm} / / \mathrm{min}$ ). The average of the maximum force necessary to shear all cores per carcass was used for statistical analysis.

\section{Blood collection}

Blood samples were collected into serum and EDTA vacutainers from the jugular vein of lambs on d 0 and d 60 for yr 1 and yr 2 of the study. Immediately after collection, blood was put on ice and transported to the Montana Veterinary Diagnostic Lab for a complete blood count (CBC). The blood count was performed on a CELL-DYN 3700 System (Abbott Laboratories, Abbott Park, IL, USA). 


\section{Internal parasites}

To evaluate which species, and the amounts of parasites that occurred in the lambs, a fecal egg count (FEC) was performed on rectal grab samples using the Modified McMaster's technique [23]. Samples were collected on days 0 and 60 in both yr 1 and yr 2. Trichostrongyle type or Nematodirus were identified and counted individually. One egg inside the grid of the slide represented 50 EPG of fresh feces.

During harvest, at the end of yr 1 and yr 2, the abomasum and first meter of the small intestine were collected at random from 4 lambs from each of the four treatments to be used for a total worm count analysis using the modified methods of Wood et al. [24]. The two organs and their contents were separated and washed thoroughly with tap water in a 20 liter bucket. The water level was brought to 10 liters and both the water and organs were left to settle for $\geq 15$ minutes. Next, the top one half to two thirds of the water was decanted and the process was repeated twice, returning the water level to 10 liters each time. After the third wash, the organ was rinsed again and disposed of and the water level was then returned to 10 liters for a final settling. After all washings had occurred and the fourth wash was decanted, the water level was returned to 10 liters, then mixed with a stir rod and 4-100 mL aliquots were taken and stored in jars with $100 \mathrm{~mL}$ of $10 \%$ formalin for later identification of adult worms in the gastrointestinal tract. The worms were plated onto slides with lactophenol and placed under a compound microscope for identification of species, via anatomical structure, and total number of each parasite was recorded.

\section{Feed analysis}

The feed was sampled weekly by grab sampling, composited for the entire experiment, and stored in sealed sample bags for analysis at a later date. All feed samples for all years, including pelleted rations and wheat stubble samples, were sent to Midwest Laboratories for nutrient analysis. Moisture, crude protein, acid detergent fiber (ADF), neutral detergent fiber (NDF), total digestible nutrients (TDN), net energy (Gain, Lactation, Maintenance), and relative feed value (RVF) were estimated using the F10: Relative Feed Value package (Table 1).

In addition to the analysis by Midwest Laboratories, all samples were analyzed for organic matter. Two 2-g samples of the 1-mm ground forage were weighed and placed in a muffle oven at $550^{\circ} \mathrm{C}$ for $15 \mathrm{~h}$ to determine ash weights for calculation of OM content [25].

\section{Data analyses}

The study design was a two by two factorial. The model included the effect of year, feeding location, and type of feed. Response variables for performance were: final lamb BW, ADG, feed efficiency, DMI, and cost per $\mathrm{kg}$ of gain. Response variables for carcass quality characteristics were: dressing percentage, hot carcass weight, back fat, rib eye area, leg score, conformation, flank streaking, quality grades, and WBSF. A year $\times$ feed $\times$ location interaction was detected for dressing percentage, abomasum T. circumcinta counts, small intestine Nematodirus counts, and total small intestine counts. Year $\times$ feed interactions were detected for ending white blood cell counts and abomasumal T. circumcinta counts. Year $\times$ location interactions were detected for DMI, ending BW, ADG, dressing percentage, and abomasum $H$. contortus counts. The data was then analyzed within year using the GLM procedure of SAS (SAS Inst, Cary, NC, USA). Beginning lamb BW was used as a covariate in the analysis of final BW and ADG. Treatment means were compared using the Least Squares Means (LSMeans) procedure when a significant $p$ value was found $(p \leq 0.10)$.

FECs were transformed to the logarithmic base 10 scale prior to analysis. The GLM procedure was run with beginning count as a covariate but it added nothing to the model and was removed. Total worm counts were also logarithmic base 10 transformed and Proc GLM was used for analysis. 


\section{RESULTS AND DISCUSSION}

\section{Performance}

In North America, confinement-finished lamb-meat production promotes rapid growth and is based on diets containing high levels of grain concentrates. The majority of research has reported that lambs grow faster on concentrate-based diets than on forage-based diets [26-35] and ad libitum consumption of concentrates results in fatter lambs compared to those fed forage diets when the lambs are slaughtered at a constant final weight [27,36,37]. However, there is a rapidly increasing demand for grass-fed or organically produced livestock [38] and in the U.S. retail sales of pasture-finished beef have risen from $\$ 17$ million in 2012 to $\$ 272$ million in 2016 [39].

A year $\times$ location interaction was detected for ending BW, ADG, and DMI; therefore results are presented by year. In yr 1 , there were no interactions between location and feed $(p>0.29)$ for all response variables (Table 2). There was also no effect of location $(p>0.42)$ on ending BW, ADG, DMI, G:F, and cost of gain. Cost of gain and DMI were greater for CALF and FALF than for CBAR and FBAR feed treatments $(p<0.01)$ across all years. G:F ratio was greater for CBAR and FBAR than CALF and FALF $(0.15,0.14,0.12$, and $0.13 \mathrm{G}$ :F respectively; $p=0.01)$.

In yr 2 , there were no interactions between location and feed $(p>0.32)$ for all response variables (Table 3). Location had an effect on ending BW and ADG, and both FALF and FBAR were greater than CALF and CBAR $(p<0.01)$. Dry matter intake, G:F ratio, and cost of gain had both a location and feed effect and differed among all treatments $(p<0.01$; Table 3$)$.

In yr 3 , there was a location $\times$ feed interaction for ending BW and ADG $(p=0.09$ and $p=$ 0.08 , respectively) (Table 4). Ending BW and ADG were greater for both FALF and FBAR than CALF and CBAR $(p<0.01)$. Feed had an effect on DMI and was greater for FALF and CALF which were similar $(p=0.03)$. This difference in DMI was expected as it has been reported that the decrease in DMI as a result of feeding higher proportion of concentrate can be attributed to the regulatory effect of dietary energy intake. Generally, animals eat food mainly to satisfy their desire for energy [40]. G:F did not differ among treatments $(p=0.53)$. Cost of gain had both a location

Table 2. Performance of crossbred lambs consuming either a forage or grain based diet while in confinement or on wheat stubble fields in yr $1^{1)}$

\begin{tabular}{|c|c|c|c|c|c|c|c|c|c|}
\hline \multirow{3}{*}{ Item } & \multicolumn{4}{|c|}{ Treatment $^{2,3)}$} & \multirow{3}{*}{ SEM } & \multicolumn{4}{|c|}{$p$-value } \\
\hline & \multicolumn{2}{|c|}{ Confinement ${ }^{4)}$} & \multicolumn{2}{|c|}{ Field $^{5)}$} & & \multirow{2}{*}{ Model } & \multirow{2}{*}{ Location $^{6)}$} & \multirow{2}{*}{ Feed $^{7)}$} & \multirow{2}{*}{$\begin{array}{l}\text { Location } \times \\
\text { Feed }\end{array}$} \\
\hline & CALF & CBAR & FALF & FBAR & & & & & \\
\hline Ending $\mathrm{BW}^{8)}(\mathrm{kg})$ & 50.6 & 50.5 & 51.3 & 49.5 & 0.78 & 0.49 & 0.85 & 0.24 & 0.30 \\
\hline$A D G(k g / d)$ & 0.25 & 0.25 & 0.26 & 0.23 & 0.01 & 0.49 & 0.83 & 0.21 & 0.30 \\
\hline $\mathrm{DMl}(\mathrm{kg} / \mathrm{d})$ & $2.09^{\mathrm{a}}$ & $1.67^{\mathrm{b}}$ & $2.09^{\mathrm{a}}$ & $1.62^{b}$ & 0.05 & $<0.01$ & 0.59 & $<0.01$ & 0.64 \\
\hline Gain to feed & $0.12^{b}$ & $0.15^{\mathrm{a}}$ & $0.13^{b}$ & $0.14^{\mathrm{a}}$ & 0.01 & 0.01 & 0.74 & 0.01 & 0.36 \\
\hline Cost of gain $(\$ / \mathrm{kg})$ & $4.33^{\mathrm{a}}$ & $3.09^{b}$ & $3.95^{\mathrm{a}}$ & $3.14^{b}$ & 0.21 & 0.00 & 0.42 & $<0.01$ & 0.29 \\
\hline
\end{tabular}

${ }^{1)}$ Start date for all treatments was September 26th.

${ }^{2)} \mathrm{Pen}$ is the experimental unit, 3 sheep per replicate confinement, 6 sheep per replicate field; six replicates per treatment.

${ }^{3}$ Diets were provided to allow for ad libitum intake.

${ }^{4}$ CALF: pellet containing $71 \%$ alfalfa, $18 \%$ barley, $5 \%$ molasses, and $6 \%$ vitamin/mineral package; CBAR: pellet containing $60 \%$ barley, $26 \%$ alfalfa, $4 \%$ molasses, $2.5 \%$ soybean-hi pro, and $7.5 \%$ vitamin/mineral package.

${ }^{5}$ FALF: field fed pellet containing $71 \%$ alfalfa, $18 \%$ barley, $5 \%$ molasses, and $6 \%$ vitamin/mineral package; FBAR: field fed pellet containing $60 \%$ barley, $26 \%$ alfalfa, $4 \%$ molasses, $2.5 \%$ soybean-hi pro, and $7.5 \%$ vitamin/mineral package.

${ }^{6)}$ Location, confinement or field finish.

${ }^{77} \mathrm{Feed}$, alfalfa or barley pellets.

${ }^{8}$ End date for field and confinement treatments was November 25th.

a, beast Square Means within a row with different superscripts differ $(p<0.10)$.

$B W$, body weight; $A D G$, average daily gain; DMI, dry matter. 
Table 3. Performance of crossbred lambs consuming either a forage or grain based diet while in confinement or on wheat stubble fields in yr $2^{1)}$

\begin{tabular}{|c|c|c|c|c|c|c|c|c|c|}
\hline \multirow{3}{*}{ Item } & \multicolumn{4}{|c|}{ Treatment $^{2,3)}$} & \multirow{3}{*}{ SEM } & \multicolumn{4}{|c|}{$p$-value } \\
\hline & \multicolumn{2}{|c|}{ Confinement $^{4)}$} & \multicolumn{2}{|c|}{ Field $^{5)}$} & & \multirow{2}{*}{ Model } & \multirow{2}{*}{ Location $^{6)}$} & \multirow{2}{*}{ Feed $^{7)}$} & \multirow{2}{*}{$\begin{array}{l}\text { Location } \times \\
\text { Feed }\end{array}$} \\
\hline & CALF & CBAR & FALF & FBAR & & & & & \\
\hline Ending $\mathrm{BW}^{8}(\mathrm{~kg})$ & $46.0^{b}$ & $45.8^{b}$ & $49.6^{a}$ & $49.2^{\mathrm{a}}$ & 0.87 & 0.01 & $<0.01$ & 0.74 & 0.84 \\
\hline$A D G(k g / d)$ & $0.24^{b}$ & $0.23^{b}$ & $0.30^{\mathrm{a}}$ & $0.29^{a}$ & 0.01 & $<0.01$ & $<0.01$ & 0.72 & 0.71 \\
\hline $\mathrm{DMI}(\mathrm{kg} / \mathrm{d})$ & $2.03^{b}$ & $1.58^{d}$ & $2.24^{\mathrm{a}}$ & $1.74^{\mathrm{c}}$ & 0.07 & $<0.01$ & 0.01 & $<0.01$ & 0.66 \\
\hline Gain to feed & $0.11^{d}$ & $0.15^{\mathrm{b}}$ & $0.13^{c}$ & $0.16^{\mathrm{a}}$ & 0.01 & $<0.01$ & $<0.01$ & $<0.01$ & 0.85 \\
\hline Cost of gain $(\$ / \mathrm{kg})$ & $4.00^{\mathrm{a}}$ & $2.74^{\mathrm{c}}$ & $3.42^{\mathrm{b}}$ & $2.00^{d}$ & 0.21 & $<0.01$ & $<0.01$ & $<0.01$ & 0.32 \\
\hline
\end{tabular}

${ }^{1)}$ Start date for all treatments was September 4th.

${ }^{2)}$ Pen is the experimental unit, 3 sheep per replicate confinement, 6 sheep per replicate field; six replicates per treatment.

${ }^{3)}$ Diets were provided to allow for ad libitum intake.

${ }^{4)}$ CALF: pellet containing $71 \%$ alfalfa, $18 \%$ barley, $5 \%$ molasses, and $6 \%$ vitamin/mineral package; CBAR: pellet containing $60 \%$ barley, $26 \%$ alfalfa, $4 \%$ molasses, $2.5 \%$ soybean-hi pro, and $7.5 \%$ vitamin/mineral package.

${ }^{5} \mathrm{FALF}$ : field fed pellet containing $71 \%$ alfalfa, $18 \%$ barley, $5 \%$ molasses, and $6 \%$ vitamin/mineral package; FBAR: field fed pellet containing $60 \%$ barley, $26 \%$ alfalfa, $4 \%$ molasses, $2.5 \%$ soybean-hi pro, and $7.5 \%$ vitamin/mineral package.

${ }^{6)}$ Location, confinement or field finish.

${ }^{7)}$ Feed, alfalfa or barley pellets.

${ }^{8)}$ End date for field and confinement treatments was November 4th.

${ }^{a-d}$ Least Square Means within a row with different superscripts differ $(p<0.10)$.

BW, body weight; $A D G$, average daily gain; DMI, dry matter.

Table 4. Performance of crossbred lambs consuming either a forage or grain based diet while in confinement or on wheat stubble fields in yr $3^{1)}$

\begin{tabular}{|c|c|c|c|c|c|c|c|c|c|}
\hline \multirow{3}{*}{ Item } & \multicolumn{4}{|c|}{ Treatment $\mathrm{t}^{2,3)}$} & \multirow{3}{*}{ SEM } & \multicolumn{4}{|c|}{$p$-value } \\
\hline & \multicolumn{2}{|c|}{ Confinement ${ }^{4)}$} & \multicolumn{2}{|c|}{ Field $^{5)}$} & & \multirow{2}{*}{ Model } & \multirow{2}{*}{ Location $^{6)}$} & \multirow{2}{*}{ Feed $^{7)}$} & \multirow{2}{*}{$\begin{array}{l}\text { Location } \times \\
\text { Feed }\end{array}$} \\
\hline & CALF & CBAR & FALF & FBAR & & & & & \\
\hline Ending $\mathrm{BW}^{8}(\mathrm{~kg})$ & $51.75^{a}$ & $50.51^{a}$ & $52.84^{b}$ & $53.73^{b}$ & 0.75 & $<0.01$ & $<0.01$ & 0.78 & 0.09 \\
\hline$A D G(k g / d)$ & $0.22^{\mathrm{a}}$ & $0.21^{a}$ & $0.24^{b}$ & $0.25^{\mathrm{b}}$ & 0.01 & $<0.01$ & $<0.01$ & 0.81 & 0.08 \\
\hline $\mathrm{DMI}(\mathrm{kg} / \mathrm{d})$ & $2.08^{a}$ & $1.86^{b}$ & $2.14^{a}$ & $2.00^{b}$ & 0.07 & 0.03 & 0.11 & $<0.01$ & 0.57 \\
\hline Gain to feed & 0.13 & 0.10 & 0.10 & 0.11 & 0.01 & 0.53 & 0.65 & 0.70 & 0.17 \\
\hline Cost of gain $(\$ / \mathrm{kg})$ & $4.15^{\mathrm{a}}$ & $3.36^{b}$ & $3.72^{\mathrm{a}}$ & $2.75^{\mathrm{c}}$ & 0.22 & $<0.01$ & $<0.01$ & $<0.01$ & 0.65 \\
\hline
\end{tabular}

${ }^{1)}$ Start date for all treatments was September 1 st.

${ }^{2)}$ Pen is the experimental unit, 3 sheep per replicate confinement, 6 sheep per replicate field; six replicates per treatment.

${ }^{3)}$ Diets were provided to allow for ad libitum intake.

${ }^{4)}$ CALF: pellet containing $71 \%$ alfalfa, $18 \%$ barley, $5 \%$ molasses, and $6 \%$ vitamin/mineral package; CBAR: pellet containing $60 \%$ barley, $26 \%$ alfalfa, $4 \%$ molasses, $2.5 \%$ soybean-hi pro, and $7.5 \%$ vitamin/mineral package.

${ }^{5}$ FALF: field fed pellet containing $71 \%$ alfalfa, $18 \%$ barley, $5 \%$ molasses, and $6 \%$ vitamin/mineral package; FBAR: field fed pellet containing $60 \%$ barley, $26 \%$ alfalfa, $4 \%$ molasses, $2.5 \%$ soybean-hi pro, and $7.5 \%$ vitamin/mineral package.

${ }^{6)}$ Location, confinement or field finish.

${ }^{7)}$ Feed, alfalfa or barley pellets.

${ }^{8)}$ End date for field and confinement treatments was November 5 th.

${ }^{a-c}$ Least Square Means within a row with different superscripts differ $(p<0.10)$.

BW, body weight; ADG, average daily gain; DMI, dry matter.

and feed effect and was highest for CALF and FALF ( $\$ 4.15 / \mathrm{kg}$ and $\$ 3.72 / \mathrm{kg}$, respectively; $p$ $<0.01)$ than CBAR and FBAR with FBAR having the lowest cost of gain $(\$ 2.75 / \mathrm{kg} ; p<0.01)$. Even though the cost of gain was greater for alfalfa fed lambs, a survey conducted by Ripoll et al. [41] reported that $70.4 \%$ of consumers surveyed believe that grass-fed lamb is better and may be willing to pay a premium price for what they perceive as a "higher-quality product". Also, Jacques et al. [42] concluded that using forage finishing systems may improve processing efficiency by reducing the amount of external fat to be removed by preventing excessively fat carcasses from 
lambs slaughtered. However, in our study there was no difference in back fat thickness among treatments ( $p \leq 0.33$; Tables 5 and 6$)$.

In yr 2 and 3, both field treatments had greater ending BW and ADG than the confinement treatments. In yr 1 , extreme weather conditions (temperatures down to $-29^{\circ} \mathrm{C}$ for $\sim 1$ week) may have affected animals in the field and had an impact on animal performance. Our results are in agreement with those of Phillips et al. [43] who reported that lambs can be adequately finished on a forage-based diet (alfalfa or kenaf) and doing so does not adversely affect performance or feed intake. McClure et al. [32] and Aurosseau et al. [44] also determined that finishing lambs on highquality forages can yield similar ADG to those achieved in confinement feeding a concentrate diet while producing comparable carcasses.

\section{Carcass}

A year $\times$ location and a year $\times$ location $\times$ feed interaction was detected for dressing percentage; therefore, results are presented by year. In yr 1 , there was no interaction between location and feed $(p>0.09)$ for all response variables (Table 5). Dressing percent differed by location but not feed; dressing percent was greater for FALF and FBAR than for CALF and CBAR (51.92\%, 52.85\%, $49.18 \%$, and $46.45 \%$ respectively; $p<0.02$ ). Rib eye area differed by location but not feed; rib eye area was greater for FALF and FBAR than for CALF and CBAR (6.03, 6.32, 5.30, and $5.33 \mathrm{~cm}^{2}$ respectively; $p<0.02$; Table 5). WBSF was greater for CALF and FALF than CBAR and FBAR $(3.8,3.8,2.7$, and $3.1 \mathrm{~kg}$ respectively; $p=0.01)$. All other carcass measurements did not differ among treatments. Nichols et al. [45] reported that lambs overwintered on stubble fields graded choice after confinement feeding; however, they did not investigate alternatives to confinement feeding.

Table 5. Carcass characteristics of crossbred lambs consuming either a forage or grain based diet while in confinement or on wheat stubble fields in $\mathrm{yr}^{1)}$

\begin{tabular}{|c|c|c|c|c|c|c|c|c|c|}
\hline \multirow{3}{*}{ Item } & \multicolumn{4}{|c|}{ Treatment $^{2,3)}$} & \multirow{3}{*}{ SEM } & \multicolumn{4}{|c|}{$p$-value } \\
\hline & \multicolumn{2}{|c|}{ Confinement $^{4)}$} & \multicolumn{2}{|c|}{ Field $^{5)}$} & & \multirow{2}{*}{ Model } & \multirow{2}{*}{ Location $^{6)}$} & \multirow{2}{*}{ Feed $^{7)}$} & \multirow{2}{*}{$\begin{array}{l}\text { Location } \times \\
\text { Feed }\end{array}$} \\
\hline & CALF & CBAR & FALF & FBAR & & & & & \\
\hline Carcass weight (kg) & 25.1 & 24.2 & 25.9 & 26.6 & 1.13 & 0.46 & 0.16 & 0.90 & 0.44 \\
\hline Dressing percent & $49.18^{b}$ & $46.45^{\mathrm{b}}$ & $51.92^{\mathrm{ab}}$ & $52.85^{\mathrm{a}}$ & 1.54 & 0.02 & 0.01 & 0.54 & 0.22 \\
\hline Back fat thickness $(\mathrm{cm})$ & 0.34 & 0.38 & 0.43 & 0.28 & 0.07 & 0.56 & 0.94 & 0.49 & 0.21 \\
\hline Ribeye area $\left(\mathrm{cm}^{2}\right)$ & $5.30^{b}$ & $5.33^{b}$ & $6.03^{\mathrm{a}}$ & $6.32^{\mathrm{a}}$ & 0.21 & $<0.01$ & $<0.01$ & 0.45 & 0.55 \\
\hline Leg score ${ }^{8)}$ & 406 & 413 & 434 & 422 & 8.56 & 0.13 & 0.04 & 0.72 & 0.28 \\
\hline Conformation $^{8)}$ & 413 & 419 & 434 & 413 & 8.08 & 0.20 & 0.34 & 0.34 & 0.09 \\
\hline Flank streaking ${ }^{9}$ & 294 & 237 & 256 & 259 & 23.99 & 0.39 & 0.73 & 0.25 & 0.21 \\
\hline Quality grade $^{8)}$ & 425 & 407 & 406 & 409 & 15.08 & 0.77 & 0.57 & 0.61 & 0.47 \\
\hline WBSF (kg) & $3.8^{\mathrm{a}}$ & $2.7^{\mathrm{b}}$ & $3.8^{\mathrm{a}}$ & $3.1^{\mathrm{b}}$ & 0.30 & 0.03 & 0.56 & $<0.01$ & 0.53 \\
\hline
\end{tabular}

${ }^{1)}$ Start date for all treatments was September 26th; End date for field and confinement treatments was November 25th.

${ }^{2)}$ Pen is the experimental unit, 3 sheep per replicate confinement, 6 sheep per replicate field; six replicates per treatment.

${ }^{3)}$ Diets were provided to allow for ad libitum intake.

${ }^{4)}$ CALF: pellet containing $71 \%$ alfalfa, $18 \%$ barley, $5 \%$ molasses, and $6 \%$ vitamin/mineral package; CBAR: pellet containing $60 \%$ barley, $26 \%$ alfalfa, $4 \%$ molasses, $2.5 \%$ soybean-hi pro, and $7.5 \%$ vitamin/mineral package.

${ }^{5)}$ FALF: field fed pellet containing $71 \%$ alfalfa, $18 \%$ barley, $5 \%$ molasses, and $6 \%$ vitamin/mineral package; FBAR: field fed pellet containing $60 \%$ barley, $26 \%$ alfalfa, $4 \%$ molasses, $2.5 \%$ soybean-hi pro, and $7.5 \%$ vitamin/mineral package.

${ }^{6)}$ Location, confinement or field finish.

${ }^{7)}$ Feed, alfalfa or barley pellets.

${ }^{8)} 325$, Good minus; 350, Good; 375, Good plus; 425, Choice minus; 450, Choice; 475, Choice plus; 525, Prime minus; 550, Prime; 575, Prime plus.

9) 100 to 199, Practically Devoid; 200 to 299, Traces; 300 to 399, Slight; 400 to 499, Small.

a,b Least Square Means within a row with different superscripts differ $(p<0.10)$.

WBSF, Warner-Bratzler shear force. 
Table 6. Carcass characteristics of crossbred lambs consuming either a forage or grain based diet while in confinement or on wheat stubble fields in $\mathrm{yr}^{1)}$

\begin{tabular}{|c|c|c|c|c|c|c|c|c|c|}
\hline \multirow[b]{3}{*}{ Item } & \multicolumn{4}{|c|}{ Treatment $^{2,3)}$} & \multirow{3}{*}{ SEM } & \multicolumn{4}{|c|}{$p$-value } \\
\hline & \multicolumn{2}{|c|}{ (onfinement ${ }^{4}$} & \multicolumn{2}{|c|}{ Field $^{5}$} & & \multirow{2}{*}{ Model } & \multirow{2}{*}{ Location $^{6}$} & \multirow{2}{*}{ Feed $^{7)}$} & \multirow{2}{*}{$\begin{array}{l}\text { Location } \times \\
\text { Feed }\end{array}$} \\
\hline & CALF & CBAR & FALF & FBAR & & & & & \\
\hline Carcass weight (kg) & 24.5 & 23.5 & 25.6 & 24.4 & 1.01 & 0.54 & 0.33 & 0.28 & 0.90 \\
\hline Dressing percent & 49.71 & 50.85 & 51.49 & 50.31 & 0.95 & 0.59 & 0.52 & 0.98 & 0.23 \\
\hline Back fat thickness $(\mathrm{cm})$ & 0.25 & 0.24 & 0.33 & 0.32 & 0.04 & 0.33 & 0.07 & 0.79 & 0.94 \\
\hline Ribeye area $\left(\mathrm{cm}^{2}\right)$ & 5.91 & 5.73 & 6.25 & 6.32 & 0.20 & 0.15 & 0.03 & 0.79 & 0.56 \\
\hline Leg score ${ }^{8)}$ & $419^{\mathrm{ab}}$ & $406^{b}$ & $438^{\mathrm{a}}$ & $431^{a}$ & 8.92 & 0.09 & 0.02 & 0.30 & 0.73 \\
\hline Conformation $^{8)}$ & $419^{\mathrm{ab}}$ & $406^{b}$ & $438^{\mathrm{a}}$ & $431^{\mathrm{a}}$ & 8.92 & 0.09 & 0.02 & 0.30 & 0.73 \\
\hline Flank streaking ${ }^{9}$ & 259 & 289 & 324 & 288 & 35.39 & 0.61 & 0.35 & 0.92 & 0.33 \\
\hline Quality grade $^{8)}$ & 403 & 419 & 443 & 413 & 21.65 & 0.59 & 0.42 & 0.72 & 0.28 \\
\hline WBSF (kg) & 4.2 & 4.3 & 4.1 & 3.7 & 0.48 & 0.76 & 0.45 & 0.67 & 0.56 \\
\hline
\end{tabular}

${ }^{1)}$ Start date for all treatments was September 4th; End date for field and confinement treatments was November 4th.

${ }^{2)}$ Pen is the experimental unit, 3 sheep per replicate confinement, 6 sheep per replicate field; six replicates per treatment.

${ }^{3)}$ Diets were provided to allow for ad libitum intake.

${ }^{4)}$ CALF: pellet containing $71 \%$ alfalfa, $18 \%$ barley, $5 \%$ molasses, and $6 \%$ vitamin/mineral package; CBAR: pellet containing $60 \%$ barley, $26 \%$ alfalfa, $4 \%$ molasses, $2.5 \%$ soybean-hi pro, and $7.5 \%$ vitamin/mineral package.

${ }^{5} \mathrm{FALF}$ : field fed pellet containing $71 \%$ alfalfa, $18 \%$ barley, $5 \%$ molasses, and $6 \%$ vitamin/mineral package; FBAR: field fed pellet containing $60 \%$ barley, $26 \%$ alfalfa, $4 \%$ molasses, $2.5 \%$ soybean-hi pro, and $7.5 \%$ vitamin/mineral package.

${ }^{6)}$ Location, confinement or field finish.

${ }^{7)}$ Feed, alfalfa or barley pellets.

${ }^{8} 325$, Good minus; 350, Good; 37, Good plus; 425, Choice minus; 450, Choice; 475, Choice plus; 525, Prime minus; 550, Prime; 575, Prime plus.

9) 100 to 199 , Practically Devoid; 200 to 299 , Traces; 300 to 399, Slight; 400 to 499, Small.

a,b Least Square Means within a row with different superscripts differ $(p<0.10)$.

WBSF, Warner-Bratzler shear force.

There was no difference in quality grade amongst treatments or years; all treatments graded in the good-plus to choice-minus range ( $p \leq 0.77$; Table 5$)$.

In yr 2 , there were no interactions between location and feed $(p>0.23)$ for all variables. Lambs in FALF and FBAR treatments tended to have greater leg scores and conformation than CALF and CBAR $(p=0.09)$. All other carcass measurements did not differ among treatments (Table 6). In our study we observed lambs in the field treatments exercising more than lambs in confinement pens; further research should be conducted to corroborate these observations and determine if exercise has an effect on leg scores and conformation. Our results are in conflict with the results of Jones et al. [46], where confinement fed lambs produced heavier carcasses and larger rib eye areas than pasture fed lambs. Our results are also in disagreement with Purchas et al. [47] who reported that WBSF values were significantly lower for M. seminembranosus in the pasture vs. grain treatments of $50 \mathrm{~kg}$ harvest weight lambs $(4.04,4.67 \mathrm{~kg}$, respectively). In our study, location did not have an effect on tenderness but WBSF was greater for CALF and FALF than CBAR and FBAR $(3.8,3.8,2.7$, and 3.1 respectively; $p=0.01)$. Both Duckett et al. [48] and Realini et al. [49] reported that WBSF values were similar between forage and concentrate-fed animals. In our trial the foragebased treatment diet and grain-based treatment diet were both in concentrate-form with the same particle size. Past studies have only investigated forage-fed (in pasture or hay form) vs. concentratefed diets and therefore may not be comparable to our study. Forage particle size influences feed intake, saliva production, rumination, and the passage rate of feed in the rumen, as well as biohydrogenation pathways and fatty acid composition in lamb meat [50]. 


\section{Blood}

A year $\times$ feed interaction was detected for ending white blood cell counts; therefore, results are presented by year. In yr 1 , there were no interactions between location and feed $(p>0.12)$ for all variables (Table 7). Both hematocrit and mean cell hemoglobin concentration were affected by feed and were greater for CALF and FALF than CBAR and FBAR $(p<0.08)$. This agrees with the results of Gawel and Grzelak [51] who reported that alfalfa concentrate may be important as a dietary supplement for animals and may improve the hematological indices of blood. Mean cell hemoglobin and red cell distribution width differed by location; FALF and FBAR were both greater than CALF and CBAR $(p<0.06)$. All other blood counts did not differ between treatments. The principal clinical sign of Haemonchus contortus (H. contortus) infections is anemia, due to the blood-letting activities of the parasite [52]. The cool season parasite T. circumcinta (formerly Ostertagia circumcinta) interferes with absorption of nutrients and may cause weight loss and possibly diarrhea [53].

In yr 2 , there were no interactions between location and feed $(p>0.38)$ for all variables (Table 8). Red blood cell counts were affected by feed and were greater for CALF and FALF than CBAR and FBAR $(p<0.07)$. The tendency for CALF to have greater white blood cell counts in yr 2, compared to other treatments, may be influenced by its abomasum T. circumcinta worm burden which was greater in CALF than all other treatments $(p=0.07)$. This would agree with the results of Ebrahim [15] who reported that blood samples taken from sheep infested with GIP had greater white blood cell counts than sheep that were parasite-free. Kowalczuk-Vasilev et al. [54] reported that the use of iron-rich alfalfa concentrate in feeding lambs significantly improved hematological blood indices: hematocrit, hemoglobin and erythrocytes (RBC), and may be due to more efficient iron absorption. Hematocrit and mean cell hemoglobin differed by location and FALF and FBAR were greater than CALF and CBAR $(p<0.08)$. Variation in factors that affect the rumen bacterial

Table 7. Whole blood counts of crossbred lambs consuming either a forage or grain based diet while in confinement or on wheat stubble fields in yr $1^{1)}$

\begin{tabular}{|c|c|c|c|c|c|c|c|c|c|}
\hline \multirow[b]{3}{*}{ Item $^{6)}$} & \multicolumn{4}{|c|}{ Treatment $^{2,3)}$} & \multirow{3}{*}{ SEM } & \multicolumn{4}{|c|}{$p$-value } \\
\hline & \multicolumn{2}{|c|}{ Confinement $^{4)}$} & \multicolumn{2}{|c|}{ Field $^{5)}$} & & \multirow{2}{*}{ Model } & \multirow{2}{*}{ Location $^{7}$} & \multirow{2}{*}{ Feed $^{8)}$} & \multirow{2}{*}{$\begin{array}{l}\text { Location } \times \\
\text { Feed }\end{array}$} \\
\hline & CALF & CBAR & FALF & FBAR & & & & & \\
\hline White blood cell & 7.34 & 7.69 & 7.46 & 7.02 & 0.43 & $<0.01$ & 0.44 & 0.90 & 0.28 \\
\hline Red blood cell & 12.99 & 12.66 & 12.92 & 12.62 & 0.32 & 0.13 & 0.82 & 0.23 & 0.95 \\
\hline Hemoglobin & 14.07 & 20.13 & 14.21 & 13.68 & 2.56 & 0.26 & 0.14 & 0.19 & 0.12 \\
\hline Hematocrit & $42.00^{\mathrm{a}}$ & $40.56^{b}$ & $42.19^{\mathrm{a}}$ & $41.28^{\mathrm{ab}}$ & 0.63 & 0.01 & 0.38 & 0.03 & 0.62 \\
\hline Mean cell volume & 32.36 & 32.21 & 41.72 & 32.83 & 7.67 & 0.70 & 0.43 & 0.47 & 0.49 \\
\hline Mean cell hemoglobin & $10.83^{\mathrm{ab}}$ & $10.62^{b}$ & $11.05^{\mathrm{a}}$ & $10.97^{\mathrm{ab}}$ & 0.18 & $<0.01$ & 0.06 & 0.34 & 0.66 \\
\hline Mean cell hemoglobin concentration & $33.43^{\mathrm{ab}}$ & $33.19^{b}$ & $33.65^{\mathrm{a}}$ & $33.25^{b}$ & 0.23 & $<0.01$ & 0.45 & 0.08 & 0.68 \\
\hline Red cell distribution width & $25.80^{\mathrm{b}}$ & $25.62^{b}$ & $26.00^{\mathrm{b}}$ & $27.26^{\mathrm{a}}$ & 0.59 & $<0.01$ & 0.06 & 0.27 & 0.14 \\
\hline
\end{tabular}

${ }^{1)}$ Start date for all treatments was September 26th; End date for field and confinement treatments was November 25th.

${ }^{2)} \mathrm{Pen}$ is the experimental unit, 3 sheep per replicate confinement, 6 sheep per replicate field; six replicates per treatment.

${ }^{3)}$ Diets were provided to allow for ad libitum intake.

${ }^{4}$ CALF: pellet containing $71 \%$ alfalfa, $18 \%$ barley, $5 \%$ molasses, and $6 \%$ vitamin/mineral package; CBAR: pellet containing $60 \%$ barley, $26 \%$ alfalfa, $4 \%$ molasses, $2.5 \%$ soybean-hi pro, and $7.5 \%$ vitamin/mineral package.

${ }^{5}$ FALF: field fed pellet containing $71 \%$ alfalfa, $18 \%$ barley, $5 \%$ molasses, and $6 \%$ vitamin/mineral package; FBAR: field fed pellet containing $60 \%$ barley, $26 \%$ alfalfa, $4 \%$ molasses, $2.5 \%$ soybean-hi pro, and $7.5 \%$ vitamin/mineral package.

${ }^{6)}$ All items are ending counts.

${ }^{7)}$ Location, confinement or field finish.

${ }^{8}$ Feed, alfalfa or barley pellets.

a,b Least Square Means within a row with different superscripts differ $(p<0.10)$. 
Table 8. Whole blood counts of crossbred lambs consuming either a forage or grain based diet while in confinement or on wheat stubble fields in yr $2^{1)}$

\begin{tabular}{|c|c|c|c|c|c|c|c|c|c|}
\hline \multirow{3}{*}{ Item $^{6)}$} & \multicolumn{4}{|c|}{ Treatment $^{2,3)}$} & \multirow{3}{*}{ SEM } & \multicolumn{4}{|c|}{$\mathrm{p}$-value } \\
\hline & \multicolumn{2}{|c|}{ Confinement ${ }^{4)}$} & \multicolumn{2}{|c|}{ Field $^{5)}$} & & \multirow{2}{*}{ Model } & \multirow{2}{*}{ Location $^{7)}$} & \multirow{2}{*}{ Feed $^{8)}$} & \multirow{2}{*}{$\begin{array}{l}\text { Location } \times \\
\text { Feed }\end{array}$} \\
\hline & CALF & CBAR & FALF & FBAR & & & & & \\
\hline White blood cell & $7.41^{\mathrm{a}}$ & $6.62^{\mathrm{ab}}$ & $7.21^{a}$ & $6.46^{b}$ & 0.38 & $<0.01$ & 0.58 & 0.02 & 0.96 \\
\hline Red blood cell & $12.28^{\mathrm{ab}}$ & $11.97^{b}$ & $12.55^{\mathrm{a}}$ & $12.08^{b}$ & 0.25 & 0.03 & 0.37 & 0.07 & 0.70 \\
\hline Hemoglobin & $13.26^{b}$ & $12.93^{\mathrm{b}}$ & $13.82^{\mathrm{a}}$ & $13.34^{\mathrm{b}}$ & 0.21 & $<0.01$ & 0.01 & 0.03 & 0.66 \\
\hline Hematocrit & $38.84^{b}$ & $38.84^{b}$ & $40.10^{a}$ & $39.28^{\mathrm{ab}}$ & 0.55 & 0.06 & 0.08 & 0.39 & 0.38 \\
\hline Mean cell volume & 31.72 & 32.20 & 32.20 & 32.62 & 0.53 & $<0.01$ & 0.33 & 0.33 & 0.94 \\
\hline Mean cell hemoglobin & $10.82^{\mathrm{ab}}$ & $10.74^{\mathrm{b}}$ & $11.04^{\mathrm{a}}$ & $11.05^{\mathrm{a}}$ & 0.12 & $<0.01$ & 0.02 & 0.75 & 0.66 \\
\hline Mean cell hemoglobin concentration & $34.15^{\mathrm{ab}}$ & $33.39^{c}$ & $34.39^{\mathrm{a}}$ & $33.92^{b}$ & 0.24 & $<0.01$ & 0.06 & $<0.01$ & 0.48 \\
\hline Red cell distribution width & 26.11 & 25.96 & 26.10 & 26.58 & 0.56 & 0.22 & 0.53 & 0.74 & 0.52 \\
\hline
\end{tabular}

${ }^{11}$ Start date for all treatments was September 4th; End date for field and confinement treatments was November 4th.

${ }^{2)} \mathrm{Pen}$ is the experimental unit, 3 sheep per replicate confinement, 6 sheep per replicate field; six replicates per treatment.

${ }^{3)}$ Diets were provided to allow for ad libitum intake.

${ }^{4)}$ CALF; pellet containing $71 \%$ alfalfa, $18 \%$ barley, $5 \%$ molasses, and $6 \%$ vitamin/mineral package; CBAR; pellet containing $60 \%$ barley, $26 \%$ alfalfa, $4 \%$ molasses, $2.5 \%$ soybean-hi pro, and $7.5 \%$ vitamin/mineral package.

${ }^{5}$ FALF; field fed pellet containing $71 \%$ alfalfa, $18 \%$ barley, $5 \%$ molasses, and $6 \%$ vitamin/mineral package; FBAR; field fed pellet containing $60 \%$ barley, $26 \%$ alfalfa, $4 \%$ molasses, $2.5 \%$ soybean-hi pro, and $7.5 \%$ vitamin/mineral package.

${ }^{6)}$ All items are ending counts.

${ }^{7)}$ Location, confinement or field finish.

${ }^{8)}$ Feed, alfalfa or barley pellets.

${ }^{a, b}$ Least Square Means within a row with different superscripts differ $(p<0.10)$.

community (diet composition, feed types, feeding strategy) can have a robust effect on rumen metabolism, which can impact both productivity and health of ruminants [55]. Hemoglobin and mean cell hemoglobin concentration had an effect of both location and feed therefore they differed between all treatments $(p<0.06)$. All other blood counts did not differ between treatments (Table 8).

\section{Parasites}

A year $\times$ location and year $\times$ feed interaction was detected for $H$. contortus worm counts along with a year $\times$ feed $\times$ location interaction for T. circumcinta worm counts, Nematodirus worm counts and small intestine total worm counts, therefore, results are presented by year $(p<0.01)$. In yr 1 , there were no interactions between location and feed $(p>0.72)$ for all variables. Ending Trichostrongyle egg counts differed at $p<0.05$. Ending Nematodirus spp. egg counts did not differ between treatments, although there was a tendency $(p=0.11)$ for CALF and FALF to be greater than CBAR and FBAR (Table 9).

In yr 1, there was an interaction between location and feed for small intestine total worm count $(p<0.01)$. FALF had a greater small intestine total worm count than all other treatments, CBAR was intermediate, and CALF and FBAR had the lowest counts (176, 18, 2, 0 small intestine worm count; $p=0.01)$. An interaction between location and feed was also present for Nematodirus worm counts $(p<0.01)$. FALF was greater $(p<0.03)$ than all other treatments, CBAR was intermediate and differed from all other treatments $(p=0.03)$ and FBAR and CALF were the lowest $(p=1.00)$. All other worm burdens in the abomasum and first meter of the small intestine did not differ among treatments (Table 10).

In yr 2 , there were no interactions between location and feed $(p>0.24)$ for all parasite variables. Ending Trichostrongyle type egg counts did not differ between all treatments (Table 11). Ending Nematodirus spp. egg counts were affected by location and feed and were greater for FALF and CALF (20.62 and 9.99 EPG respectively; $p>0.30$ ), however CALF did not differ from FBAR 
Table 9. Ending counts of internal parasite eggs per gram (EPG) in crossbred lambs consuming either a forage or grain based diet while in confinement or on wheat stubble fields in yr $1^{1)}$

\begin{tabular}{|c|c|c|c|c|c|c|c|c|c|}
\hline \multirow[b]{3}{*}{ Item ${ }^{6)}$} & \multicolumn{4}{|c|}{ Treatment $^{2,3)}$} & \multirow{3}{*}{ SEM } & \multicolumn{4}{|c|}{$p$-value } \\
\hline & \multicolumn{2}{|c|}{ Confinement $^{4)}$} & \multicolumn{2}{|c|}{ Field $^{5)}$} & & \multirow{2}{*}{ Model } & \multirow{2}{*}{ Location $^{7)}$} & \multirow{2}{*}{ Feed $^{8)}$} & \multirow{2}{*}{$\begin{array}{l}\text { Location } \times \\
\text { Feed }\end{array}$} \\
\hline & CALF & CBAR & FALF & FBAR & & & & & \\
\hline Nematodirus spp. EPG & 10.57 & 3.34 & 12.98 & 2.67 & 0.58 & 0.11 & 0.98 & 0.02 & 0.72 \\
\hline
\end{tabular}

${ }^{1)}$ Start date for all treatments was September 26th; End date for field and confinement treatments was November 25th.

${ }^{2)}$ Pen is the experimental unit, 3 sheep per replicate confinement, 6 sheep per replicate field; six replicates per treatment.

${ }^{3)}$ Diets were provided to allow for ad libitum intake.

${ }^{4)}$ CALF: pellet containing $71 \%$ alfalfa, $18 \%$ barley, $5 \%$ molasses, and $6 \%$ vitamin/mineral package; CBAR: pellet containing $60 \%$ barley, $26 \%$ alfalfa, $4 \%$ molasses, $2.5 \%$ soybean-hi pro, and $7.5 \%$ vitamin/mineral package.

${ }^{5)}$ FALF: field fed pellet containing $71 \%$ alfalfa, $18 \%$ barley, $5 \%$ molasses, and $6 \%$ vitamin/mineral package; FBAR: field fed pellet containing $60 \%$ barley, $26 \%$ alfalfa, $4 \%$ molasses, $2.5 \%$ soybean-hi pro, and $7.5 \%$ vitamin/mineral package.

${ }^{6}$ All counts had an addition of a constant of 1 then were LOG transformed.

${ }^{7)}$ Location, confinement or field finish.

${ }^{8)}$ Feed, alfalfa or barley pellets.

Table 10. Worm burden in the abomasum and first meter of the small intestine in crossbred lambs consuming either a forage or grain based diet while in confinement or on wheat stubble fields in $\mathrm{yr}^{11}{ }^{1)}$

\begin{tabular}{|c|c|c|c|c|c|c|c|c|c|}
\hline \multirow[b]{3}{*}{ Item $^{6)}$} & \multicolumn{4}{|c|}{ Treatment $^{2,3)}$} & \multirow{3}{*}{ SEM } & \multicolumn{4}{|c|}{$p$-value } \\
\hline & \multicolumn{2}{|c|}{ Confinement ${ }^{4)}$} & \multicolumn{2}{|c|}{ Field $^{5)}$} & & \multirow{2}{*}{ Model } & \multirow{2}{*}{ Location $^{7}$} & \multirow{2}{*}{ Feed $^{8)}$} & \multirow{2}{*}{$\begin{array}{l}\text { Location } \times \\
\text { Feed }\end{array}$} \\
\hline & CALF & CBAR & FALF & FBAR & & & & & \\
\hline Abomasum total count & 3 & 24 & 111 & 10 & 1.09 & 0.20 & 0.25 & 0.88 & 0.07 \\
\hline Teladorsagia circumcincta & 3 & 24 & 111 & 10 & 1.09 & 0.20 & 0.25 & 0.88 & 0.07 \\
\hline Small intestine total count & $2^{\mathrm{bc}}$ & $18^{\mathrm{b}}$ & $176^{\mathrm{a}}$ & $0^{c}$ & 0.94 & 0.01 & 0.48 & 0.08 & $<0.01$ \\
\hline Teladorsagia circumcincta & 2 & 0 & 0 & 0 & 0.59 & 0.47 & 0.38 & 0.38 & 0.38 \\
\hline Nematodirus & $0^{c}$ & $18^{\mathrm{b}}$ & $176^{\mathrm{a}}$ & $0^{c}$ & 0.72 & $<0.01$ & 0.12 & 0.12 & $<0.01$ \\
\hline
\end{tabular}

${ }^{1}$ Start date for all treatments was September 26th; End date for field and confinement treatments was November 25th.

${ }^{2)}$ Pen is the experimental unit, 3 sheep per replicate confinement, 6 sheep per replicate field; six replicates per treatment.

${ }^{3)}$ Diets were provided to allow for ad libitum intake.

${ }^{4)}$ CALF: pellet containing $71 \%$ alfalfa, $18 \%$ barley, $5 \%$ molasses, and $6 \%$ vitamin/mineral package; CBAR: pellet containing $60 \%$ barley, $26 \%$ alfalfa, $4 \%$ molasses, $2.5 \%$ soybean-hi pro, and $7.5 \%$ vitamin/mineral package.

${ }^{5)} \mathrm{FAL}$ : field fed pellet containing $71 \%$ alfalfa, $18 \%$ barley, $5 \%$ molasses, and $6 \%$ vitamin/mineral package; FBAR: field fed pellet containing $60 \%$ barley, $26 \%$ alfalfa, $4 \%$ molasses, $2.5 \%$ soybean-hi pro, and $7.5 \%$ vitamin/mineral package.

${ }^{6)} \mathrm{All}$ Counts had an addition of a constant of 1 then were LOG transformed.

${ }^{7)}$ Location, confinement or field finish.

${ }^{8)}$ Feed, alfalfa or barley pellets.

${ }^{a-c}$ Least Square Means within a row with different superscripts differ $(p<0.10)$.

(5.60 EPG; $p>0.44$ ), and CBAR was lowest and differed from all other treatments (0.52 EPG; $p$ $<0.03$ ). It is unknown why CBAR had the lowest EPG in yr 2 but there was a tendency for both barley treatment groups to have lower EPG than the field treatments. It is widely accepted that a high grain diet causes a drop in ruminal $\mathrm{pH}$ and may cause drastic shifts in the rumen microbial community [56-59]. Ruminal bacterial and protozoal populations increase or decrease in response to $\mathrm{pH}$ changes [57], however, the effect of $\mathrm{pH}$ on internal parasites has not been studied. It is possible that a lamb's rumen environment is less favorable to internal parasites while consuming a high grain (barley) diet and thus we see lower EPG in these lambs; more research is needed to investigate this relationship.

In yr 2 , there were no interactions $(p>0.11)$ between location and feed for all parasite variables. Abomasum H. contortus worm burden was greater in CALF than all other treatments $(p=0.07)$. All other worm burdens in the abomasum and first meter of the small intestine did not differ 
Table 11. Ending counts of internal parasite eggs per gram (EPG) in crossbred lambs consuming either a forage or grain based diet while in confinement or on wheat stubble fields in $\mathrm{yr}^{1)}$

\begin{tabular}{|c|c|c|c|c|c|c|c|c|c|}
\hline \multirow{3}{*}{ Item $^{6}$} & \multicolumn{4}{|c|}{ Treatment $^{2,3)}$} & \multirow{3}{*}{ SEM } & \multicolumn{4}{|c|}{$p$-value } \\
\hline & \multicolumn{2}{|c|}{ Confinement $^{4)}$} & \multicolumn{2}{|c|}{ Field $^{5)}$} & & \multirow{2}{*}{ Model } & \multirow{2}{*}{ Location $^{7)}$} & \multirow{2}{*}{ Feed $^{8)}$} & \multirow{2}{*}{$\begin{array}{l}\text { Location } \times \\
\text { Feed }\end{array}$} \\
\hline & CALF & CBAR & FALF & FBAR & & & & & \\
\hline Trichostrongyle type EPG & 50.92 & 10.97 & 28.51 & 18.31 & 0.51 & 0.29 & 0.92 & 0.04 & 0.24 \\
\hline Nematodirus spp. EPG & $9.99^{\mathrm{ab}}$ & $0.52^{\mathrm{c}}$ & $20.62^{\mathrm{a}}$ & $5.60^{\mathrm{b}}$ & 0.53 & $<0.01$ & 0.02 & $<0.01$ & 0.40 \\
\hline
\end{tabular}

${ }^{1)}$ Start date for all treatments was September 4th; End date for field and confinement treatments was November 4th.

${ }^{2)}$ Pen is the experimental unit, 3 sheep per replicate confinement, 6 sheep per replicate field; six replicates per treatment.

${ }^{3)}$ Diets were provided to allow for ad libitum intake.

${ }^{4)}$ CALF: pellet containing $71 \%$ alfalfa, $18 \%$ barley, $5 \%$ molasses, and $6 \%$ vitamin/mineral package; CBAR: pellet containing $60 \%$ barley, $26 \%$ alfalfa, $4 \%$ molasses, $2.5 \%$ soybean-hi pro, and $7.5 \%$ vitamin/mineral package.

${ }^{5}$ FALF: field fed pellet containing $71 \%$ alfalfa, $18 \%$ barley, $5 \%$ molasses, and $6 \%$ vitamin/mineral package; FBAR: field fed pellet containing $60 \%$ barley, $26 \%$ alfalfa, $4 \%$ molasses, $2.5 \%$ soybean-hi pro, and $7.5 \%$ vitamin/mineral package.

${ }^{6)}$ All counts had an addition of a constant of 1 then were LOG transformed.

${ }^{7)}$ Location, confinement or field finish.

${ }^{8)}$ Feed, alfalfa or barley pellets.

${ }^{\mathrm{a}-\mathrm{c}}$ Least Square Means within a row with different superscripts differ $(p<0.10)$.

Table 12. Worm burden in the abomasum and first meter of the small intestine in crossbred lambs consuming either a forage or grain based diet while in confinement or on wheat stubble fields in $\mathrm{yr}^{1)}$

\begin{tabular}{|c|c|c|c|c|c|c|c|c|c|}
\hline \multirow{3}{*}{ Item $^{6}$} & \multicolumn{4}{|c|}{ Treatment ${ }^{2,3)}$} & \multirow{3}{*}{ SEM } & \multicolumn{4}{|c|}{$p$-value } \\
\hline & \multicolumn{2}{|c|}{ Confinement $^{4)}$} & \multicolumn{2}{|c|}{ Field $^{5)}$} & & \multirow{2}{*}{ Model } & \multirow{2}{*}{ Location ${ }^{7)}$} & \multirow{2}{*}{ Feed $^{8)}$} & \multirow{2}{*}{$\begin{array}{l}\text { Location } \times \\
\text { Feed }\end{array}$} \\
\hline & CALF & CBAR & FALF & FBAR & & & & & \\
\hline Abomasum total count & 49 & 15 & 12 & 44 & 1.50 & 0.88 & 0.93 & 0.98 & 0.44 \\
\hline Teladorsagia circumcincta & 41 & 15 & 12 & 44 & 1.48 & 0.90 & 0.98 & 0.94 & 0.47 \\
\hline Haemonchus contortus & $6^{a}$ & $0^{b}$ & $0^{\mathrm{b}}$ & $0^{b}$ & 0.57 & 0.07 & 0.11 & 0.11 & 0.11 \\
\hline Small Intestine total count & 29 & 0 & 3 & 3 & 1.10 & 0.23 & 0.74 & 0.14 & 0.16 \\
\hline Teladorsagia circumcincta & 2 & 0 & 0 & 0 & 0.58 & 0.43 & 0.34 & 0.34 & 0.34 \\
\hline Nematodirus & 8 & 0 & 3 & 3 & 1.14 & 0.60 & 0.86 & 0.32 & 0.37 \\
\hline
\end{tabular}

${ }^{1)}$ Start date for all treatments was September 4th; End date for field and confinement treatments was November 4th.

${ }^{2)}$ Pen is the experimental unit, 3 sheep per replicate confinement, 6 sheep per replicate field; six replicates per treatment.

${ }^{3)}$ Diets were provided to allow for ad libitum intake.

${ }^{4)}$ CALF:pellet containing $71 \%$ alfalfa, $18 \%$ barley, $5 \%$ molasses, and $6 \%$ vitamin/mineral package; CBAR: pellet containing $60 \%$ barley, $26 \%$ alfalfa, $4 \%$ molasses, $2.5 \%$ soybean-hi pro, and $7.5 \%$ vitamin/mineral package.

${ }^{5}$ FALF: field fed pellet containing $71 \%$ alfalfa, $18 \%$ barley, $5 \%$ molasses, and $6 \%$ vitamin/mineral package; FBAR: field fed pellet containing $60 \%$ barley, $26 \%$ alfalfa, $4 \%$ molasses, $2.5 \%$ soybean-hi pro, and $7.5 \%$ vitamin/mineral package.

${ }^{6)}$ All counts had an addition of a constant of 1 then were LOG transformed.

${ }^{7)}$ Location, confinement or field finish.

${ }^{8)}$ Feed, alfalfa or barley pellets.

a,b Least Square Means within a row with different superscripts differ $(p<0.10)$.

among treatments (Table 12). Marley et al. [60] determined that legume forages have the potential to contribute to the control of abomasal but not small intestine nematode parasites in finishing lamb systems. This is in contrast to our results where alfalfa-fed lambs in confinement had greater abomasum T. circumcinta worm counts than other treatments.

Parasite results are in conflict with those of Cai and Bai [14] who reported that gastrointestinal nematode EPG were lowest in lambs fed in confinement and highest in grazing lambs. FEC in our study appeared to trend with barley fed animals having lower counts than those of alfalfa fed animals. Studies have shown that the degree of parasite infestation in sheep may be reduced by some plant species [61-63]. Research has focused on the effects of secondary plant compounds (e.g. condensed tannins) [64] on the reduction of parasites in the gut but the underlying mechanisms 
for such effects have not been determined. Overall in our study FEC worm counts taken from all slaughtered lambs were low and likely did not adversely influence the weight gains and hematocrit levels of the lambs.

Integrated crop and livestock systems as an alternative to confinement feedlot operations may increase marketing opportunities for sheep producers. While field finishing lambs with a grain- or forage-based diet, we conclude that it is possible to produce a quality lamb product without adverse effects to animal performance, carcass quality or increasing parasite burdens.

\section{REFERENCES}

1. Meyer D, Mullinax DD. Livestock nutrient management concerns: regulatory and legislative overview.J Anim Sci. 1999;77:51-62.https://doi.org/10.2527/1999.77suppl_251x

2. Blay ET, Danquah EY, Ofosu-Anim J, Ntumy JK. Effect of poultry manure and/or inorganic fertilizer on the yield of shallot [Allium cepa var. aggregatum (g. Don)]. Adv Hortic Sci. 2002;16:13-6.

3. Ofosu-Anim J, Leitch M. Relative efficacy of organic manures in spring barley (Hordeum vulgare L.) production. Aust J Crop Sci. 2009;3:13-9.

4. Phan TC RM, Cong DS. Beneficial effects of organic amendment on improving phosphorus availability and decreasing aluminium toxicity in two upland soils of vitnam. In: Proceedings of the World congress of Soil Science; 2020; Bangkok, Thailand. p. 14-21.

5. Snyder EE, Goosey HB, Hatfield PG, Lenssen AW. Sheep grazing wheat summer fallow and the impact on soil nitrogen, moisture, and crop yield. In: Proceedings of the American Society of Animal Science Western Section; 2007; Illinois, USA. p. 221-4.

6. Goosey HB, Hatfield PG, Blodgett SL, Cash SD. Evaluation of alfalfa weevil (Coleoptera: Curculionidae) densities and regrowth characteristics of alfalfa grazed by sheep in winter and spring.J Entomol Sci. 2004;39:598-610. https://doi.org/10.18474/0749-8004-39.4.598

7. Goosey HB, Hatfield PG, Lenssen AW, Blodgett SL, Kott RW. The potential role of sheep in dryland grain production systems. Agric Ecosyst Environ. 2005;111:349-53. https://doi. org/10.1016/j.agee.2005.06.003

8. Hatfield PG, Blodgett SL, Spezzano TM, Goosey HB, Lenssen AW, Kott RW, et al. Incorporating sheep into dryland grain production systems: I. Impact on over-wintering larva populations of wheat stem sawfly, Cephus cinctus Norton (Hymenoptera: Cephidae). Small Rumin Res. 2007;67:209-15. https://doi.org/10.1016/j.smallrumres.2005.10.002

9. United States Department of Agriculture [USDA]. Lamb from farm to table [Internet]. 2013 [cited 2021 Jan 22]. https:/www.fsis.usda.gov/wps/portal/fsis/topics/food-safety-education/ get-answers/food-safety-fact-sheets/meat-preparation/focus-on-lambfrom-farm-to-table/ct_ index

10. Min BR, Hart SP.Tannins for suppression of internal parasites.J Anim Sci. 2003;81:E102-9.

11. Waller PJ. Sustainable nematode parasite control strategies for ruminant livestock by grazing management and biological control. Anim Feed Sci Technol. 2006;126:277-89. https://doi. org/10.1016/j.anifeedsci.2005.08.007

12. Kimambo AE, MacRae JC, Walker A, Watt CF, Coop RL. Effect of prolonged subclinical infection with Trichostrongylus colubriformis on the performance and nitrogen metabolism of growing lambs. Vet Parasitol. 1988;28:191-203. https://doi.org/10.1016/0304-4017(88)90107-0

13. Min BR, Pomroy WE, Hart SP, Sahlu T. The effect of short-term consumption of a forage containing condensed tannins on gastro-intestinal nematode parasite infections in grazing wether goats. Small Rumin Res. 2004;51:279-83. https://doi.org/10.1016/S0921-4488(03)00204-9 
14. Cai KZ, Bai JL. Infection intensity of gastrointestinal nematodosis and coccidiosis of sheep raised under three types of feeding and management regims in Ningxia Hui autonomous region, china. Small Rumin Res. 2009;85:111-5. https://doi.org/10.1016/j.smallrumres.2009.07.013

15. Ebrahim ZK. Effect of gastrointestinal parasites infestation on some hematological and biochemical parameters in sheep. Alex J Vet Sci. 2018;59:44-7.

16. Blackburn HD, Snowder GD, Glimp H. Simulation of lean lamb production systems. J Anim Sci. 1991;69:115-24. https://doi.org/10.2527/1991.691115x

17. Font i Furnols M, Realini C, Montossi F, Sañudo C, Campo MM, Oliver MA, et al. Consumer's purchasing intention for lamb meat affected by country of origin, feeding system and meat price: a conjoint study in Spain, France and United Kingdom. Food Qual Prefer. 2011;22:44351. https://doi.org/10.1016/j.foodqual.2011.02.007

18. Barroso J, Miller ZJ, Lehnhoff EA, Hatfield PG, Menalled FD. Impacts of cropping system and management practices on the assembly of weed communities. Weed Res. 2015;55:426-35. https://doi.org/10.1111/wre.12155

19. Johnson S. Effects of organic and conventional cropping systems on plant diversity and plant soil feedbacks [M.S. thesis]. Bozeman, MT: Montana State University; 2015.

20. Lehnhoff E, Miller Z, Miller P, Johnson S, Scott T, Hatfield P, et al. Organic agriculture and the quest for the holy grail in water-limited ecosystems: managing weeds and reducing tillage intensity. Agriculture. 2017;7:33. https://doi.org/10.3390/agriculture7040033

21. Ragen DL BM, Miller PR, Yeoman CJ, Meccage EC, Weeding JL, Hatfield PG. Soil microbial, chemical and physical properties in tilled organic, conventional no-till, and organic integrated crop-livestock systems [Authors' unpublished material]. 2020.

22. Mendes EDM, Carstens GE, Tedeschi LO, Pinchak WE, Friend TH. Validation of a system for monitoring feeding behavior in beef cattle. J Anim Sci. 2011;89:2904-10. https://doi. org/10.2527/jas.2010-3489

23. Whitlock HV. Some modifications of the mcmaster helminth egg-counting technique and apparatus. J Counc Sci Ind Res. 1948;21:177-80.

24. Wood IB, Amaral NK, Bairden K, Duncan JL, Kassai T, Malone JB Jr, et al. World association for the advancement of veterinary parasitology (w.A.A.V.P.) second edition of guidelines for evaluating the efficacy of anthelmintics in ruminants (bovine, ovine, caprine). Vet Parasitol. 1995;58:181-213. https://doi.org/10.1016/0304-4017(95)00806-2

25. AOAC [Association of Official Analytical Chemists] International. Official methods of analysis of AOAC International. 19th ed. Arlington, VA: AOAC International; 2012.

26. Taylor MA. Parasite control in sheep: a risky business. Small Rumin Res. 2013;110:88-92. https://doi.org/10.1016/j.smallrumres.2012.11.010

27. Archimède H, Pellonde P, Despois P, Etienne T, Alexandre G. Growth performances and carcass traits of ovin martinik lambs fed various ratios of tropical forage to concentrate under intensive conditions. Small Rumin Res. 2008;75:162-70. https://doi.org/10.1016/j.smallrumres.2007.10.001

28. Borton RJ, Loerch SC, McClure KE, Wulf DM. Characteristics of lambs fed concentrates or grazed on ryegrass to traditional or heavy slaughter weights. ii. wholesale cuts and tissue accretion. J Anim Sci. 2005;83:1345-52. https://doi.org/10.2527/2005.8361345x

29. Demirel G, Ozpinar H, Nazli B, Keser O. Fatty acids of lamb meat from two breeds fed different forage: concentrate ratio. Meat Sci. 2006;72:229-35. https://doi.org/10.1016/j.meatsci.2005.07.006

30. Fimbres H, Hernández-Vidal G, Picón-Rubio JF, Kawas JR, Lu CD. Productive performance and carcass characteristics of lambs fed finishing ration containing various forage levels. Small 
Rum Res. 2002;43:283-8. https://doi.org/10.1016/S0921-4488(02)00014-7

31. McClure KE, Solomont MB, Loerch SC. Body weight and tissue gain in lambs fed an all-concentrate diet and implanted with trenbolone acetate or grazed on alfalfa. J Anim Sci. 2000;78:1117-24. https://doi.org/10.2527/2000.7851117x

32. McClure KE, Van Keuren RW, Althouse PG. Performance and carcass characteristics of weaned lambs either grazed on orchardgrass, ryegrass, or alfalfa or fed all-concentrate diets in drylot.J Anim Sci. 1994;72:3230-7. https://doi.org/10.2527/1994.72123230x

33. Murphy TA, Loerch SC, McClure KE, Solomon MB. Effects of grain or pasture finishing systems on carcass composition and tissue accretion rates of lambs. J Anim Sci. 1994;72:3138-44. https://doi.org/10.2527/1994.72123138x

34. Turner KE, McClure KE, Weiss WP, Borton RJ, Foster JG. Alpha-tocopherol concentrations and case life of lamb muscle as influenced by concentrate or pasture finishing. J Anim Sci. 2002;80:2513-21. https://doi.org/10.1093/ansci/80.10.2513

35. Notter DR, Kelly RF, McClaugherty FS. Effects of ewe breed and management system on efficiency of lamb production: ii. lamb growth, survival and carcass characteristics. J Anim Sci. 1991;69:22-33. https://doi.org/10.2527/1991.69122x

36. Fisher AV, Enser M, Richardson RI, Wood JD, Nute GR, Kurt E, et al. Fatty acid composition and eating quality of lamb types derived from four diverse breed $\times$ production systems. Meat Sci. 2000;55:141-7. https://doi.org/10.1016/S0309-1740(99)00136-9

37. Resconi VC, Campo MM, Furnols MFi, Montossi F, Sañudo C. Sensory evaluation of castrated lambs finished on different proportions of pasture and concentrate feeding systems. Meat Sci. 2009;83:31-7.https://doi.org/10.1016/j.meatsci.2009.03.004

38. Greene C, Kremen A. U.S. organic farming in 2000-2001: adoption of certified systems. Washington, DC: USDA Economic Research Service; 2003. Report No.: AIB-780.

39. Cheung R, Paul M. Back to grass: the market potential for U.S. grassfed beef. New York, NY: Stone Barns Center for Food and Agriculture; 2017.

40. Van Soest PJ, Ferreira AM, Hartley RD. Chemical properties of fibre in relation to nutritive quality of ammonia-treated forages. Anim Feed Sci Technol. 1984;10:155-64. https://doi. org/10.1016/0377-8401(84)90005-1

41. Ripoll G, Joy M, Panea B. Consumer perception of the quality of lamb and lamb confit. Foods. 2018;7:80. https://doi.org/10.3390/foods7050080

42. Jacques J, Berthiaume R, Cinq-Mars D. Growth performance and carcass characteristics of dorset lambs fed different concentrates: forage ratios or fresh grass. Small Rumin Res. 2011;95:113-9. https://doi.org/10.1016/j.smallrumres.2010.10.002

43. Phillips WA, Reuter RR, Brown MA, Fitch JQ, Rao SR, Mayeux H. Growth and performance of lambs fed a finishing diet containing either alfalfa or kenaf as the roughage source. Small Rumin Res. 2002;46:75-9. https://doi.org/10.1016/S0921-4488(02)00176-1

44. Aurousseau B, Bauchart D, Faure X, Galot AL, Prache S, Micol D, et al. Indoor fattening of lambs raised on pasture. Part 1: influence of stall finishing duration on lipid classes and fatty acids in the longissimus thoracis muscle. Meat Sci. 2007;76:241-52. https://doi.org/10.1016/ j.meatsci.2006.11.005

45. Nichols ME. Feedlot performance and carcass characteristics: comparison of small, medium, and large frame wethers backgrounded on wheat pasture [Master's thesis]. Manhattan, KS: Kansas State University; 1990.

46. Jones SDM, Burgess TD, Dupchak K, Pollock E. The growth performance and carcass composition of ram and ewe lambs fed on pasture or in confinement and slaughtered at similar fatness. Can J Anim Sci. 1984;64:631-40. https://doi.org/10.4141/cjas84-072 
47. Purchas RW, O'Brien LE, Pendleton CM. Some effects of nutrition and castration on meat production from male suffolk cross (border leicester-romney cross) lambs. N Z J Agric Res. 1979;22:375-83. https://doi.org/10.1080/00288233.1979.10430763

48. Duckett SK, Neel JPS, Lewis RM, Fontenot JP, Clapham WM. Effects of forage species or concentrate finishing on animal performance, carcass and meat quality. J Anim Sci. 2013;91:1454-67. https://doi.org/10.2527/jas.2012-5914

49. Realini CE, Duckett SK, Brito GW, Dalla Rizza M, De Mattos D. Effect of pasture vs. concentrate feeding with or without antioxidants on carcass characteristics, fatty acid composition, and quality of Uruguayan beef. Meat Sci. 2004;66:567-77. https://doi.org/10.1016/S03091740(03)00160-8

50. Santos-Silva J, Mendes IA, Portugal PV, Bessa RJB. Effect of particle size and soybean oil supplementation on growth performance, carcass and meat quality and fatty acid composition of intramuscular lipids of lambs. Livest Prod Sci. 2004;90:79-88. https://doi.org/10.1016/ j.livprodsci.2004.02.013

51. Gaweł E, Grzelak M. The effect of a protein-xanthophyll concentrate from alfalfa (phytobiotic) on animal production: a current review. Ann Anim Sci. 2012;12:281-9. https://doi. org/10.2478/v10220-012-0023-5

52. Baker NF, Cook EF, Douglas JR, Cornelius CE. The pathogenesis of trichostrongyloid parasites. iii. some physiological observations in lambs suffering from acute parasitic gastroenteritis. J Parasitol. 1959;45:643-51.

53. Urquhart GM, Armour J, Duncan JL, Dunn AM, Jennings FW. Veterinary parasitology. 2nd ed. Oxford, UK: Elsevier; 1996.

54. Kowalczuk-Vasilev E KR, Patkowski K. Effect of px concentrate of alfalfa (Medicago sativa) on haematological indices of lambs' blood. In: Grela E, editor. Alfalfa in human and animal nutrition. Lublin, Poland: Stowarzyszenia Rozwoju Regionalnego i Lokalnego "PROGRESS"; 2010. p. 186-7.

55. Asma Z, Sylvie C, Laurent C, Jérôme M, Christophe K, Olivier B, et al. Microbial ecology of the rumen evaluated by $454 \mathrm{gs}$ flx pyrosequencing is affected by starch and oil supplementation of diets. FEMS Microbiol Ecol. 2013;83:504-14. https://doi.org/10.1111/1574-6941.12011

56. Bo Trabi E, Seddik He, Xie F, Wang X, Liu J, Mao S. Effect of pelleted high-grain total mixed ration on rumen morphology, epithelium-associated microbiota and gene expression of proinflammatory cytokines and tight junction proteins in hu sheep. Anim Feed Sci Technol. 2020;263:1144-53. https://doi.org/10.1016/j.anifeedsci.2020.114453

57. Fernando SC, Purvis HT, Najar FZ, Sukharnikov LO, Krehbiel CR, Nagaraja TG, et al. Rumen microbial population dynamics during adaptation to a high-grain diet. Appl Environ Microbiol. 2010;76:7482-90. https://doi.org/10.1128/aem.00388-10

58. Khafipour E, Li S, Plaizier JC, Krause DO. Rumen microbiome composition determined using two nutritional models of subacute ruminal acidosis. Appl Environ Microbiol. 2009;75:711524. https://doi.org/10.1128/aem.00739-09

59. Tajima K, Aminov RI, Nagamine T, Matsui H, Nakamura M, Benno Y. Diet-dependent shifts in the bacterial population of the rumen revealed with real-time pcr. Appl Environ Microbiol. 2001;67:2766-74. https://doi.org/10.1128/aem.67.6.2766-2774.2001

60. Marley CL, Fraser MD, Fychan R, Theobald VJ, Jones R. Effect of forage legumes and anthelmintic treatment on the performance, nutritional status and nematode parasites of grazing lambs. Vet Parasitol. 2005;131:267-82. https://doi.org/10.1016/j.vetpar.2005.04.037

61. Niezen JJ, Waghorn TS, Raufaut K, Robertson HA, McFarlane R. Lamb weight gain and faecal egg count when grazing one of seven herbages and dosed with larvae for six weeks. In: 
Proceedings of the New Zealand Society of Animal Production; 1994.p. 15.

62. Marley CL, Cook R, Keatinge R, Barrett J, Lampkin NH. The effect of birdsfoot trefoil (Lotus corniculatus) and chicory (Cichorium intybus) on parasite intensities and performance of lambs naturally infected with helminth parasites. Vet Parasitol. 2003;112:147-55. https://doi. org/10.1016/s0304-4017(02)00412-0

63. Scales GH, Knight TL, Saville DJ. Effect of herbage species and feeding level on internal parasites and production performance of grazing lambs. N Z J Agric Res. 1995;38:237-47. https:// doi.org/10.1080/00288233.1995.9513124

64. Athanasiadou S, Kyriazakis I, Jackson F, Coop RL. Effects of short-term exposure to condensed tannins on adult Trichostrongylus colubriformis. Vet Rec. 2000;146:728-32. https://doi. org/10.1136/vr.146.25.728 